\title{
Mirroring Transitional Justice. Construction and Impact of European Union ICTY-Conditionality
}

\begin{abstract}
The European Union (EU) developed a state-building strategy for the aspiring member states in the Western Balkans. Demanding full cooperation with the International Criminal Tribunal for the former Yugoslavia (ICTY), the EU made transitional justice part of the accession demands. Scholars have recently criticized the EU's limited focus on retributive justice as opposed to restorative justice. This paper goes beyond such impact-orientated analyses by asking why the EU engaged with retributive transitional justice in the first place. The EU constructed ICTY-conditionality by mirroring its own post-Second World War experiences to the envisioned post-conflict trajectory of the Western Balkans. The EU therefore expected the court to contribute to reconciliation, democratization and the rule of law. Using Serbia as a case study, this article examines the conditionality's context, specificities and discursive claims. Finally, it relates these findings to the agenda of a promising regional initiative prioritizing restorative justice (RECOM) and sheds new light on the impact of ICTY-conditionality on transitional justice in the Western Balkans.
\end{abstract}

Niké Wentholt is a PhD candidate at the Department of Contemporary History, University of Groningen.

\section{Introduction}

When Yugoslavia fell apart in the first half of the 1990s, the $\mathrm{EU}^{1}$ was confronted with multiple violent conflicts in its immediate neighbourhood. After initial hesitation to intervene during the wars, the EU committed itself to post-conflict

* A draft version of this paper was presented at the conference 'The More They Changed', 9-10 October 2014 in Ankara. I would like to thank all the participants, and especially the organizers and moderators, Dr Timofey Agarin and Dr Gözde Yilmaz, for their insightful and valuable comments that have hugely benefited this paper. I am also grateful to an anonymous reviewer for very helpful, constructive feedback. It is because of a doctoral grant provided by the Netherlands Organization for Scientific Research (NWO) and the excellent supervision by Prof Antoon de Baets and Dr Sipke de Hoop that this paper could be written.

${ }^{1}$ In the course of decades, but also in more recent years, both the institutional make-up and the names for this partnership have drastically changed. For the sake of continuity, I consistently refer to 'EU' throughout this paper, even when I discuss its formal predecessors. 
peace-building. Because all Western Balkan countries were seeking EU membership in the course of the early 2000s, this peace-building engagement was institutionalized in the form of accession policy. A strong focus on democratization and rule of law characterized this enlargement framework. ${ }^{2}$ As Soeren Keil and Zeynep Arkan recently demonstrated, the EU slowly but unmistakably took on the role of 'state builder' - albeit with little previous expertise and experience. ${ }^{3}$ In this process, the Western Balkan countries were to become functional and democratic European member states. What is more, as Olivera Simić rightly highlighted, the EU expected these states to be 'able to deal with the past'. 4

The EU, therefore, augmented its accession demands to include so-called transitional justice. ${ }^{5}$ As defined by the International Center for Transitional Justice, the leading expert institute, this is the

'set of judicial and non-judicial measures that have been implemented by different countries in order to redress the legacies of massive human rights abuses. These measures include criminal prosecutions, truth commissions, reparations programs, and various kinds of institutional reforms. ${ }^{6}$

Academic literature often uses this distinction between judicial and non-judicial measures to analyse the different goals of retributive and restorative justice. Whereas retributive justice aims to prosecute perpetrators for past crimes, restorative justice seeks to address the present needs of victims. ${ }^{7}$ By making cooperation with the ICTY an absolute condition for membership, the EU strongly prioritized retributive justice mechanisms.

The EU's blindness to restorative justice in the Western Balkans is astonishing to scholars well aware of today's lessons on the need for victim-centred reconciliation. Experts now argue that the EU's focus on the ICTY was too

2 Soeren Keil / Zeynep Arkan, The Limits of Normative Power? EU Member State Building in the Western Balkans, in: Soeren Keil / Zeynep Arkan, eds, The EU and Member State Building. European Foreign Policy in the Western Balkans, New York et al. 2015, 15-31, 18; Iva Vukušić, Successes and Failures of Transitional Justice in BiH. The Case of the ICTY, in: Soeren Keil / Valery Perry, eds, State Building and Democratization in Bosnia and Herzegovina, Farnham, Burlington 2015, 151-171, 154.

3 Soeren Keil / Zeynep Arkan, Introduction. The European Union and Member State Building - European Union Foreign Policy in the Western Balkans, in: Keil / Arkan, eds, The EU and Member State Building, 3-14, 6; Keil / Arkan, The Limits of Normative Power?, 15-16.

4 Olivera Simić, The European Union and the Western Balkans. Time to Move Away from Retributive Justice?, in: Keil / Arkan, eds, The EU and Member State Building, 191-208, 192.

${ }^{5}$ Jasna Dragović-Soso / Eric Gordy, Coming to Terms with the Past. Transitional Justice and Reconciliation in the Post-Yugoslav Lands, in: Dejan Djokić/James Ker-Lindsay, eds, New Perspectives on Yugoslavia. Issues and Controversies, Abingdon, New York 2011, 193-212, 193.

${ }^{6}$ International Center for Transitional Justice, What is Transitional Justice?, https://www. ictj.org/about/transitional-justice. All internet references were accessed on 4 December 2016.

7 Alette Smeulers / Fred Grünfeld, International Crimes and Other Gross Human Rights Violations, Boston et al. 2011, 440, 463, 479. 
narrow ${ }^{8}$ and did not target civil society. ${ }^{9}$ As a result, ICTY-conditionality failed to diffuse norms of justice and reconciliation to the domestic realm. Although it was part of the EU's broader state-building efforts, ICTY-conditionality did little to enhance processes of democratization and rule of law. ${ }^{10}$ These analyses of ICTY-conditionality's impact are to the point and insightful.

However, the novelty of the EU's engagement with transitional justice merits critical exploration of the motives behind the incorporation of retributive justice as a state-building device. The expectations and 'construction and malleability' of a condition matter, as Gwendolyn Sasse has underlined, in understanding its eventual impact. ${ }^{11}$ Hence, this article consists of three parts, with Serbia as case study. In the first part, I posit that the EU recognized its own war-torn history in the break-up of Yugoslavia. Mirroring its own post-Second World War experiences, the EU believed that ICTY-cooperation would contribute to reconciliation and to state-building in general.

The second part applies Dvora Yanow's method of interpretive policy analysis to various types of EU documents. ${ }^{12}$ Reading 'back and forth' between 'policy or agency artifacts' as conveyers of meaning and 'context', I combine historical reconstruction with discourse analysis. ${ }^{13}$ In this way, a first subsection examines how the EU's expectations of retributive justice fitted the international expectations surrounding the ICTY. A second subsection shows how these assumptions shaped the specific formulation, evaluation and implementation of the condition.

8 Simić, The European Union and the Western Balkans, 193, 197; Vukušić, Successes and Failures of Transitional Justice in BiH, 153, 159-161.

9 Soeren Keil / Zeynep Arkan, Theory and Practice of EU Member State Building in the Western Balkans, in: Soeren Keil / Zeynep Arkan, eds, The EU and Member State Building, 235-239, 238.

${ }^{10}$ Máire Braniff, Integrating the Balkans. Conflict Resolution and the Impact of EU Expansion, London 2011, 135-138; Dragović-Soso / Gordy, Coming to Terms with the Past, 197; Gergana Noutcheva, European Foreign Policy and the Challenges of Balkan Accession. Conditionality, Legitimacy and Compliance, Abingdon 2012; Victor Peskin, International Justice in Rwanda and the Balkans. Virtual Trials and the Struggle for State Cooperation, Cambridge 2008; Simić, The European Union and the Western Balkans, 194-195; Marlene Spoerri, Justice Imposed. How Policies of Conditionality Effect Transitional Justice in the Former Yugoslavia, Europe-Asia Studies 63, no. 10 (2011), 1827-1851, 1831, 1841, DOI: 10.1080/09668136.2011.618682; Jelena Subotić, Hijacked Justice. Dealing with the Past in the Balkans, Ithaca/NY et al. 2009.

11 Gwendolyn Sasse, The Politics of EU Conditionality. The Norm of Minority Protection During and Beyond EU Accession, Journal of European Public Policy 15, no. 6 (2008), 842-860, 845, DOI: 10.1080/13501760802196580.

12 I have studied primary research material in the form of European Commission enlargement strategies, progress reports, European Parliament reports and resolutions on progress reports, press releases and speeches.

13 Dvora Yanow, Conducting Interpretive Policy Analysis, London 2000, 14, 15, 22; Dvora Yanow, Thinking Interpretively. Philosophical Presuppositions and the Human Sciences, in: Peregrine Schwartz-Shea / Dvora Yanow, eds, Interpretation and Method. Empirical Research Methods and the Interpretive Turn, New York 2006, 5-26, 16. 
The third subsection studies how the EU's historically informed expectations were reflected in its discourse on the ICTY's contribution to reconciliation.

The last part of the article combines the findings of the first and second part to analyse the EU's justifications for ICTY-conditionality. These created a significant 'discursive context for domestic actors, policies and institutions' ${ }^{14}$ This proves particularly relevant to understanding the potential of the RECOM initiative ${ }^{15}$ aimed at restorative justice. This article acknowledges the valid critique that Europeanization often fails to take into account domestic factors. But instead of looking at this domestic context to explain the disappointing impact of the ICTY-conditionality, it finds elucidation within the EU's construction of this approach itself.

\section{Designing a Post-Conflict Trajectory towards Justice, Reconciliation and Democratization. The Western Balkans as the EU's Mirror Image}

With the present academic attention for transitional justice, it may be difficult to appreciate the novelty of the EU engaging with dealing with the past in the Western Balkans. Transitional justice was and is not a standard component of enlargement policy. ${ }^{16}$ State-building, let alone transitional justice, had not been a part of accession conditionality towards the Central and Eastern European states, which struggled with a demanding post-communist transition. The EU favourably perceived these countries, entering the EU in 2004 and 2007, as 'young democracies' in need of mere 'institutional stability' $\cdot{ }^{17}$ In fact, the main EU institutions articulated that dealing with the past belonged to these states' national competence, and fell outside the EU's mandate. ${ }^{18}$

14 Kennet Lynggaard, Discursive Institutional Analytical Strategies, in: Theofanis Exadaktylos / Claudio M. Radaelli, eds, Research Design in European Studies. Establishing Causality in Europeanization, New York et al. 2013, 85-104, 85.

15 RECOM is a regional commission for the establishment of facts about war crimes and other serious violations of human rights committed in the former Yugoslavia from January $1^{\text {st }} 1991$ until December $31^{\text {st }} 2001$ cf. http://www.recom.link/about-us-2/sta-je-rekom/.

16 María Avello, European Efforts in Transitional Justice, FRIDE: Fundación para las Relaciones Internacionales y el Diálogo Exterior Working Paper 58, June 2008, 1-18, 8-9, http:// fride.org/descarga/WP58_Transitional_justice_ENG_sep08.pdf; Katy A. Crossley-Frolick, The European Union and Transitional Justice. Human Rights and Post-Conflict Reconciliation and Europe and Beyond, Contemporary Readings in Law and Social Justice 3, no. 1 (2011), 33-57, 37, http://heinonline.org/HOL/AuthorProfile?collection=journals\&search_name=Crossley-Frolick,\%20Katy\%20A; Laura Davis, EU Foreign Policy, Transitional Justice and Mediation. Principle, Policy and Practice, New York et al. 2014, 11.

17 Keil / Arkan, The Limits of Normative Power?, 15.

18 Mr Barrot stated in 2009 on behalf of the EC: '[...] it is for each Member State to find its own way of coming to terms with their past, of meeting the expectations of victims and their descendants, and of achieving reconciliation. The role of the EU can only be to facil- 
There are plenty of reasons to justify the different transitional justice and state-building strategies towards, on the one hand, Central and Eastern Europe and, on the other hand, the Western Balkans. A first explanation points at growing enlargement fatigue. The complexity of the 2004 and 2007 rounds of accession and their problematic aftermath had EU member states tighten their accession demands. The chronology of this argument, however, does not hold. The EU had already started to demand ICTY-cooperation in the early 2000s, yet even in 2004 and 2007 did not ask the twelve post-communist Central and Eastern European countries on its doorstep to 'confront the past'. Another explanation relies on the actual different trajectories these countries followed. In the famous words of Winston Churchill, the Western Balkan region 'had produced far more history than they could possibly consume' ${ }^{19}$ The popularity of this quote, whether rightly or wrongly attributed to Churchill, illustrates the widely held perception that the Western Balkans carried an even heavier burden of history than Central and Eastern Europe. Scholars and practitioners nonetheless apply the concept of transitional justice equally to post-communist and post-conflict transition. Both types of transitions, despite their inherent differences, revolve

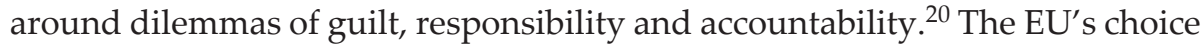
to commit itself to retributive transitional justice in the Western Balkans thus remains worthy of further examination.

The interest in dealing with the past in the Western Balkans, I argue, derived from the EU's own specific historical experiences and the memory thereof. In the violent break-up of the former Yugoslavia, the EU discerned the old, now

itate this process [...].' European Commission, Parliamentary Questions, Answer Given by Mr Barrot on Behalf of the Commission to E-0501/2009, OJ C 189, 13 July 2010, http:// www.europarl.europa.eu/sides/getAllAnswers.do?reference=E-2009-0501\&language=EN. Similar pre- and post-accession statements can be found in: Council of the European Union, Parliamentary Questions, Reply to E-0468/2006, OJC 328, 30 December 2006, http:// www.europarl.europa.eu/sides/getAllAnswers.do?reference=E-2006-0468\&language=EN; Council of the European Union, Parliamentary Questions, Joint Reply to Written Questions E-1261/06, E-1263/06, E-1265/06, http://www.europarl.europa.eu/sides/getAllAnswers. do? reference=E-2006-1261\&language $=E N$; Council of the European Union, Parliamentary Questions, Reply to E-4991/2006, OJ C 291, 13 November 2008, http://www.europarl.europa. eu/sides/getAllAnswers.do?reference=E-2006-4991\&language=EN; European Commission, Parliamentary Questions, Answer Given by Mr Frattini on Behalf of the Commission to E-3237/2007, OJ C 45, 16 February 2008, http://www.europarl.europa.eu/sides/getAllAnswers. do? reference=E-2007-3237\&language=EN; European Commission, Parliamentary Questions, Joint Answer Given By Mr Barrot on Behalf of the Commission to Written Questions E-3416/08 and E-3417/08, OJ C 999, 1 January 2009, http://www.europarl.europa.eu/sides/getAllAnswers. do? reference $=\mathrm{E}-2008-3416 \&$ language $=\mathrm{EN}$.

19 Winston Churchill, as quoted or paraphrased cf. Charles Ingrao, Confronting the Yugoslav Controversies: The Scholars' Initiative, American Historical Review 114, no. 4 (2009), 947-962, 947, DOI: 10.1086/ahr.114.4.947.

20 Arthur Paige, How ‘Transitions' Reshaped Human Rights. A Conceptual History of Transitional Justice, Human Rights Quarterly 31, no. 2 (2009), 321-367, 360, DOI: 10.1353/hrq.0.0069. 
despised, Europe characterized by conflict and nationalist rivalry. Its own war-torn past, most notably symbolized by the Holocaust, was the EU's most fundamental 'Other' ${ }^{21}$ Whereas the EU had little familiarity with communist authoritarianism, Yugoslavia had shown once more how nationalist conflict could take a whole region to the brink of devastation. No matter how complex and challenging, such violence was something that the EU had experience in overcoming.

In the EU's founding narrative, it was the coming together of former rivals that had paved the way for Western Europe's prosperous path to democracy after the destructive Second World War. Just as the French-German friendship had led to Western European integration, the EU understood reconciliation to be a prerequisite to transforming the Western Balkans into democratic EU member states. ${ }^{22}$ In 2009, the European Parliament (EP) confirmed that interethnic dialogue was needed to 'overcome both the burden of the past and tensions in relations between the countries of the Balkan region' ${ }^{23}$ In that same year, the European Commissioner for Enlargement Olli Rehn declared that the former Yugoslavia, like France and Germany some decades before, 'needs to overcome the wounds of the war' in order to become part of the 'European project'. ${ }^{24}$ At an ICTY-conference in Brussels, he urged participants to 'definitely close the dark chapters of the recent Balkan wars, and allow the countries of the region to move towards EU integration'. ${ }^{25}$ A speech from 2012 by Herman van Rompuy, then president of the European Council, is even more illustrative:

'Making peace to build the future: this is what France, Germany and others started, three generations ago. Substituting the bloody battlefields with negotiation rooms in Brussels. Putting age-old rivalries about borders or minorities to rest, and replacing them with a will to live together, to belong together. These principles are still at the core of our Union. They still form a powerful force for change. Today we stand reminded by the determination of countries such as Croatia and Serbia to cast away the shadows of the past, and live up to their European vocation. ${ }^{26}$

${ }^{21}$ Stefan Auer, The European Union's Politics of Identity and the Legacy of 1989, Humanities Research 16, no. 3 (2010), 135-150, 135, http://press-files.anu.edu.au/downloads/press/p24291/ pdf/ch123.pdf; Thomas Diez, Constructing the Self and Changing Others: Reconsidering 'Normative Power Europe', Millennium. Journal of International Studies 33, no. 3 (2005), 613-636, 634, DOI: 10.1177/03058298050330031701; Aline Sierp, History, Memory and Trans-European Identity. Unifying Divisions, New York et al. 2014, 1, 133, 136.

22 Simić, The European Union and the Western Balkans, 191-193.

${ }^{23}$ European Parliament, Consolidating Stability and Prosperity in the Western Balkans, European Parliament Resolution of 24 April 2009 on Consolidating Stability and Prosperity in the Western Balkans P6_TA(2009)0331, Strasbourg 2009, http://www.europarl.europa.eu/ sides/getDoc.do?type=TA\&language=EN\&reference=P6-TA-2009-0331.

24 Olli Rehn, Victims Always Deserve Justice and Truth, SPEECH/09/167, Brussels 2009, 2, http://europa.eu/rapid/press-release_SPEECH-09-167_en.htm.

25 Rehn, Victims Always Deserve Justice and Truth, 2.

${ }^{26}$ European Council, The President Herman Van Rompuy, Speech to the Parliament of Romania, Joint Meeting of the Chamber of Deputies and of the Senate EUCO 68/12, PRESSE 


\title{
From Expectations to Construction. Explaining the Specificities of ICTY-Conditionality
}

\author{
International and Historical Expectations. \\ Retributive Justice as International Ideal and European Value
}

The EU's understanding of the reconciled, modern and democratic self was more than a mere inspirational narrative to transfer to the Western Balkans. It concretely shaped the EU's enlargement state-building strategy. The emphasis on 'regional cooperation and good neighbourly relations' is a first indication of the practical implications of the EU's idea that 'being European' was the result of regional reconciliation. It formed a consistent element of the annual progress reports on Serbia and other communications issued by the European Commission (EC). ${ }^{27}$ Progress on the EU membership path was not only a reward for and an indication of, but also 'the best way' for successfully addressing 'inter-ethnic or status issues' impeding regional stability. ${ }^{28}$ This 'essential' process was evaluated beyond concrete diplomatic activity. ${ }^{29}$ Positive references to airlinks

170, Bucharest 2012, 2, http://www.consilium.europa.eu/uedocs/cms_data/docs/pressdata/ en/ec/129766.pdf.

${ }^{27}$ Until the Lisbon Treaty of 2009, the EC was called the Commission of the European Communities. For the sake of coherence, the Commission of the European Communities is here also denoted as the EC.

${ }^{28}$ European Commission, Communication from the Commission to the European Parliament and the Council, Enlargement Strategy and Main Challenges 2012-2013 COM(2012) 600 final, Brussels 2012, 7, http://ec.europa.eu/enlargement/pdf/key_documents/2012/package/ strategy_paper_2012_en.pdf.

29 Commission of the European Communities, Commission Staff Working Document, Serbia Progress Report 2006 SEC(2006) 1389, Brussels 8.11.2006, 17, http://ec.europa.eu/enlargement/pdf/key_documents/2006/nov/sr_sec_1389_en.pdf; Commission of the European Communities, Communication from the Commission to the European Parliament and Council, Enlargement Strategy and Main Challenges 2007-2008 COM(2007) 663 final, Brussels 2007, 18, http://ec.europa.eu/enlargement/pdf/key_documents/2007/nov/strategy_paper_en.pdf; Commission of the European Communities, Commission Staff Working Document, Serbia Progress Report 2008 SEC(2008) 2698, Brussels 5.11.2008, 20, http://ec.europa.eu/enlargement/pdf/press_corner/key-documents/reports_nov_2008/serbia_progress_report_en.pdf; Commission of the European Communities, Commission Staff Working Document, Serbia Progress Report 2009 SEC(2009) 1339, Brussels 2009, 21, http://ec.europa.eu/enlargement/ pdf/key_documents/2009/sr_rapport_2009_en.pdf; European Commission, Commission Staff Working Document, Serbia Progress Report 2010 SEC(2010) 1330, Brussels 9.11.2010, 20, http://ec.europa.eu/enlargement/pdf/key_documents/2010/package/sr_rapport_2010_en.pdf; European Commission, Commission Staff Working Paper, Analytical Report Accompanying the Document 'Communication from the Commission to the European Parliament and the Council. Commission Opinion on Serbia's Application for Membership of the European Union' SEC(2011) 1208, Brussels 2011, 35, http://ec.europa.eu/enlargement/pdf/key_documents/2011/ package/sr_analytical_rapport_2011_en.pdf; European Commission, Communication from the Commission to the European Parliament and the Council, Enlargement Strategy and Main Challenges 2011-2012 COM(2011) 666 final, Brussels 2011, 3, http://ec.europa.eu/en- 
connecting Belgrade and Tirana, ${ }^{30}$ concern with Serbian-Albanian animosities during a football game, ${ }^{31}$ or ongoing bilateral 'dispute[s]' between domestic churches, ${ }^{32}$ for example, testify to the EU's appreciation of both political and sociocultural cross-border regional cooperation in line with its own inclusive understanding of post-war regional reconciliation. Other important regional reconciliation tools were diplomatic apologies and war-crimes prosecution, with the EU's demand for ICTY-cooperation thus serving both as indicator of good regional relations and as accession criterion in itself.

This focus on retributive justice derived from the EU's projection of its own experiences with the Nuremberg trials onto the Western Balkans. The Nuremberg court prosecuted several perpetrators and, according to many, brought justice to a devastated continent by focusing on individual criminal responsibility. ${ }^{33}$ For the longest time, this European success story, together with similar trials in Tokyo, was the world's first encounter with international criminal justice. Although the idea did not disappear after Nuremberg and Tokyo, the bipolar world after 1950 lacked a 'neutral' space that could facilitate another international court. ${ }^{34}$ However, the conflicts in the former Yugoslavia coincided with the end of the Cold War. This created the perfect conditions for the United Nations (UN) to establish the ICTY in 1993. Specifically, Serbia's cooperation with the ICTY, as the country hosting the most indictees, became the 'test case' ${ }^{\prime 35}$ or 'laboratory' ${ }^{36}$ of this long-awaited second chance to realize the ideal of international criminal justice.

largement/pdf/key_documents/2011/package/strategy_paper_2011_en.pdf; European Commission, Commission Staff Working Document, Serbia 2012 Progress Report SWD(2012) 333 final, Brussels 2012, 20, http://ec.europa.eu/enlargement/pdf/key_documents/2012/package/ sr_rapport_2012_en.pdf; European Commission, Enlargement Strategy and Main Challenges 2012-2013 COM(2012) 600 final, 7; European Commission, Commission Staff Working Document, Serbia 2013 Progress Report SWD(2013) 412 final, Brussels 2013, 12; European Commission, Serbia Progress Report 2014, Brussels October 2014, 15, http://ec.europa.eu/ enlargement/pdf/key_documents/2014/20140108-serbia-progress-report_en.pdf; European Commission, Commission Staff Working Document, Serbia 2015 Report SWD(2015) 211 final, Brussels 10.11.2015, 20, http://ec.europa.eu/enlargement/pdf/key_documents/2015/20151110_ report_serbia.pdf.

30 European Commission, Serbia Progress Report 2014, 15-16.

31 European Commission, Serbia 2015 Report, 20.

32 Commission of the European Communities, Serbia Progress Report 2007, 18; Commission of the European Communities, Serbia Progress Report 2008, 23; Commission of the European Communities, Serbia Progress Report 2009, 22; European Commission, Serbia Progress Report 2010, 21; European Commission, Serbia Progress Report 2012, 21; European Commission, Serbia Progress Report 2013, 13.

33 Isabelle Delpla, How Has the ICTY Changed Our Perceptions of War?, Südosteuropa. Zeitschrift für Politik und Gesellschaft 61, no. 4 (2013), 543-554, 544.

${ }^{34}$ Smeulers / Grünfeld, International Crimes and Other Gross Human Rights Violations, 17.

35 Subotić, Hijacked Justice, 38, 47.

36 Dragović-Soso / Gordy, Coming to Terms with the Past, 193. 
At first, the EU depicted its ICTY-conditionality as an effective means to enforce Serbia's compliance with retributive justice as an international obligation. In the course of years, the EU increasingly portrayed Serbia's cooperation with the court as a symbol of the state's 'Europeanness'. At the Western Balkans summit in Thessaloniki in 2003, the EU had declared with regards to the ICTY that 'providing justice for war crimes is a legal, political and moral imperative to which we [not specified, N.W.] are all committed'. ${ }^{37}$ When Radovan Karadžić was arrested in July 2008, the notion of 'becoming European' had apparently entered the discourse. Rehn enthusiastically welcomed the arrest of this suspect, charged with a wide variety of war crimes, as a 'milestone' in Serbia's path 'towards a European future' ${ }^{38}$ The spokesperson for Rehn's colleague Javier Solana emphasized the 'excellent operation' of the Serbian authorities that 'will bring Serbia closer to European values'. ${ }^{39}$ In 2011, van Rompuy connected the two tiers. Shortly after the arrest of Ratko Mladić, a Bosnian Serb commander charged with various crimes including the genocide in Srebrenica, van Rompuy congratulated Serbian president Boris Tadić with this accomplishment 'not only for Serbia, but for the region and international justice as well'. ${ }^{40}$ Two months later, van Rompuy depicted the arrest of Goran Hadžić as 'a further important step for Serbia in realising its European perspective' and 'equally crucial for international justice' ${ }^{41}$

It is worth noting that to a certain extent this duality was adopted in Serbian discourse as well. In Serbia's National Programme for EU integration of 2009, ICTY-cooperation is the first topic in the subsection of 'international obligations'. As the document states, Serbia considers cooperation with the court 'primarily [...] in the context of acceptance, upgrading and respect of the values and rule of law as recognized in European countries' ${ }^{42}$ Serbia understood that, by that time, the ICTY-condition signified commitment to both a universal ideal and

37 EU Western Balkans Summit, Thessaloniki Declaration, 21 June 2003 C/03/163 10229/03, Thessaloniki 2003, 2, http://europa.eu/rapid/press-release_PRES-03-163_en.htm.

38 Braniff, Integrating the Balkans, 125-126; EU: Karadžić Arrest Important Step, B92, 22 July 2008, http://www.b92.net/eng/news/politics.php?yyyy=2008\&mm=07\&dd=22\&nav_id=52102.

39 EU: Karadžić Arrest Important Step.

40 European Council, The President, Speech by President Herman van Rompuy at the $1^{\text {st }}$ Serbia-EU Forum 'Overcoming the Crisis, Moving towards the European Union' EUCO 70/11 PRESSE 305, Brussels 2011, 3, http://www.consilium.europa.eu/uedocs/cms_data/docs/ pressdata/en/ec/124542.pdf.

41 European Council, The President, Joint Statement by President van Rompuy, President Barroso and High Representative Ashton on the Arrest of Goran Hadžić EUCO 53/11 PRESSE 257, Brussels 2011, https://www.consilium.europa.eu/uedocs/cms_data/docs/pressdata/en/ ec/123971.pdf.

42 Republic of Serbia, The Government, Amended National Programme for Integration of the Republic of Serbia into the European Union, Belgrade 2009, 40, http://www.seio.gov.rs/ upload/documents/NPI/npi_2009-10_incl_annexes_eng.pdf. 
a European identity. Through retributive justice in the form of ICTY-cooperation, Serbia was supposed to achieve reconciliation that would contribute to regional stability and enable the EU to build a successful member state.

\section{Practicalities of Conditionality. Formulating, Evaluating, and Implementing Retributive Justice}

As the perceived basis for a European, democratic future, cooperation with the ICTY became a non-negotiable part of the membership demands. The EU hence used its most powerful instrument of 'reinforcement by reward': full conditionality. ${ }^{43}$ Progress reports and other EC communications consistently and elaborately discussed ICTY-cooperation. ${ }^{44}$ In the important Stabilization and Association Agreement (SAA), signed in 2008, Article 4 referred to 'full cooperation with the ICTY' ${ }^{45}$

The broad formulation of the condition allowed for various components of cooperation, including archival disclosure, fact-finding, information sharing and extraditions to the ICTY. The EC's annual progress reports, which assessed Serbia's efforts towards EU membership, reflected the wide scope of this definition. The documents from 2006 onwards all started with a reference to the progress made. They emphasized the government's 'good work concerning waiver or witnesses and access to documents', 46 'significant progress', 47 'major step[s] forward' 48

43 Frank Schimmelfennig/Ulrich Sedelmeier, Governance by Conditionality. EU Rule Transfer to the Candidate Countries of Central and Eastern Europe, Journal of European Public Policy 11, no. 4 (2004), 661-679, 664-667, DOI: 10.1080/1350176042000248089; Simić, The European Union and the Western Balkans, 193.

44 Commission of the European Communities, Serbia Progress Report 2006, 15; Commission of the European Communities, Enlargement Strategy 2007-2008, 6; Commission of the European Communities, Serbia Progress Report 2008, 21, 23; Commission of the European Communities, Serbia Progress Report 2009, 19, 23; European Commission, Serbia Progress Report 2010, 18, 21; European Commission, Analytical Report, Commission Opinion 2011, 33; European Commission, Enlargement Strategy 2011-2012, 3; European Commission, Serbia 2012 Progress Report, 18-19; European Commission, Serbia 2013 Progress Report, 11; European Commission, Serbia Progress Report 2014, 14; European Commission, Serbia 2015 Report, 19, 21.

45 Member States of the European Union and Serbia, Stabilisation and Association Agreement Between the European Communities and Their Member States of the One Part, and the Republic of Serbia, of the Other Part, CE/SE/en, Brussels 2008, 13, http://ec.europa.eu/ enlargement/pdf/serbia/key_document/saa_en.pdf.

46 Commission of the European Communities, Serbia Progress Report 2006, 15.

47 Commission of the European Communities, Serbia Progress Report 2008, 21, 23.

48 This referred to the arrest of Radovan Karadžić cf. Commission of the European Communities, Communication from the Commission to the European Parliament and Council, Enlargement Strategy and Main Challenges 2008-2009 COM (2008) 674 final, Brussels 2008, 50, http://ec.europa.eu/enlargement/pdf/press_corner/key-documents/reports_nov_2008/ strategy_paper_incl_country_conclu_en.pdf. 
'further progress', 49 'improved cooperation', 50 'active' cooperation ${ }^{51}$ and 'adequate' responsiveness. ${ }^{52}$

Nonetheless, the evaluation of the condition was eventually rather negative. The progress reports concluded that 'full cooperation' with the ICTY was not achieved yet because of the remaining fugitives. ${ }^{53}$ More specifically, all reports referred to the necessity of Mladić's arrest. ${ }^{54}$ In an adopted resolution, the EP reminded Serbia that 'only apprehension and extradition of the fugitives to The Hague can be deemed the most convincing evidence of full cooperation' ${ }^{55}$ After the 2011 extradition of Hadžić as the last remaining fugitive, the EC and EP indeed declared that Serbia's ICTY-cooperation had achieved a 'fully' and 'entirely' 'satisfactory level'. ${ }^{56}$ The subcriterion of fugitives' arrest thus dominated the assessment of full cooperation with remarkable consistency.

Although this stern evaluation leads one to expect a similarly strict implementation, sanctions and rewards were adjusted to the domestic political situation in Serbia. The combination of the condition's width in formulation and firmness of evaluation enabled the EU to 'incentivise and bargain' with relevant pro-reform

49 Commission of the European Communities, Serbia Progress Report 2009, 19; Commission of the European Communities, Communication from the Commission to the European Parliament and Council, Enlargement Strategy and Main Challenges 2009-2010 COM(2009) 533, Brussels 2009, 57, http://ec.europa.eu/enlargement/pdf/key_documents/2009/strategy_paper_2009_en.pdf.

${ }^{50}$ Commission of the European Communities, Serbia Progress Report 2009, 19.

51 European Commission, Communication from the Commission to the European Parliament and Council, Enlargement Strategy and Main Challenges 2010-2011 COM(2010) 660, Brussels 2010, 17, http://ec.europa.eu/enlargement/pdf/key_documents/2010/package/ strategy_paper_2010_en.pdf.

52 European Commission, Serbia Progress Report 2010, 18.

53 Commission of the European Communities, Serbia Progress Report 2006, 16; Commission of the European Communities, Serbia Progress Report 2009, 19-20; Commission of the European Communities, Enlargement Strategy 2007-2008, 6, 17; Commission of the European Communities, Enlargement Strategy 2008-2009, 4, 9, 14, 48; European Commission, Serbia Progress Report 2010, 21; European Commission, Enlargement Strategy 2010-2011, 17.

${ }_{54}$ Commission of the European Communities, Serbia Progress Report 2006, 18; Commission of the European Communities, Serbia Progress Report 2008, 21; Commission of the European Communities, Serbia Progress Report 2009, 19; European Commission, Serbia Progress Report 2010, 18.

55 European Parliament, Stabilisation and Association Agreement between the EC and Serbia, European Parliament Resolution of 19 January 2011 on the European Integration Process of Serbia P7_TA(2011)0014, Strasbourg 2011, 4, http://www.europarl.europa.eu/sides/getDoc. do?pubRef=-//EP//TEXT+TA+P7-TA-2011-0014+0+DOC+XML+V0//EN.

56 European Commission, Analytical Report, Commission Opinion 2011, 33; European Parliament, Enlargement Report for Serbia, European Parliament Resolution of 29 March 2012 on the European Integration Process of Serbia P7_TA(2012)0114, Strasbourg 2012, 3, http://www.europarl.europa.eu/sides/getDoc.do?pubRef=-//EP//TEXT+TA+P7-TA-20120114+0+DOC+XML+V0//EN. 
authorities. ${ }^{57}$ For example, in 2005 the Council of the European Union declared itself ' mindful of the forthcoming anniversary of the democratic uprising in October 2000'. ${ }^{58}$ A historical reconstruction of two key events in 2006 and 2008, both meant to enforce extradition of the remaining fugitives, further illustrates how implementation grew more sensitive to the specific domestic political context.

When the EU stepped up its pressure in 2006, the political power balance in Serbia was stark and fixed. Prime Minister Vojislav Koštunica had limited room for political manoeuvring, because his party relied on the support of the geopolitically conservative Socialists - not to mention that he was already a stark opponent of the ICTY, which he accused of being an 'American court' ${ }^{59}$ Unwilling and unable to give in to the EU's pressure, he therefore declared that 'Mladić is hiding all by himself' ${ }^{60}$ Prompted by this reluctant attitude, the EU made continuation of the SAA negotiations conditional upon Mladić's extradition. Having once extended the deadline due to Serbian promises, on 3 May the EU decided to block the negotiations when these promises proved hollow. The Netherlands, as an individual member state, played a significant role in this decision. While the head of the delegation responsible for EU negotiations, Miroljub Labus, resigned, the Serbian government continued its work without major changes and without strengthening its efforts to capture Mladić. ${ }^{61}$ It would take more than a year for the SAA negotiations to be resumed. ${ }^{62}$

In January 2008 the EU's aim was the same. Nevertheless, both the political situation and the EU's strategy were different-and so was the outcome. Since 2007, a more pro-EU coalition had come to power in Serbia. Despite failing to capture Mladić, the coalition improved ICTY-cooperation. The new government had already managed to reopen the frozen SAA negotiations in June $2007 .{ }^{63}$ The upcoming parliamentary and presidential elections in the first half of 2008 further added to this political momentum. Perhaps recognizing this timely opportunity, in January 2008 the Netherlands again used its power as an individual member state to prevent the SAA from entering into force. Similar to

57 Braniff, Integrating the Balkans, 124.

58 Council of the European Union, Press Release, 2679 ${ }^{\text {th }}$ Council Meeting, General Affairs and External Relations C/05/242, Luxembourg 2005, 8, http://europa.eu/rapid/press-release_ PRES-05-242_en.htm?locale=en.

59 Frank Schimmelfennig, EU Political Accession Conditionality after the 2004 Enlargement. Consistency and Effectiveness, Journal of European Public Policy 15, no. 6 (2008), 918-937, 930, DOI: 10.1080/13501760802196861.

60 EU Talks Called Off, B92, 3 May 2006, http://www.b92.net/eng/news/politics.php?yyyy= $2006 \& m m=05 \& d d=03 \& n a v \_i d=34718$.

61 Robert Bideleux / Ian Jeffries, The Balkans. A Post-Communist History, New York et al. 2007, 318-319; Schimmelfennig, EU Political Accession Conditionality, 930.

62 Bideleux/Jeffries, The Balkans, 319.

63 Braniff, Integrating the Balkans, 125; Peskin, International Justice in Rwanda and the Balkans, 86; Schimmelfennig, EU Political Accession Conditionality, 930. 
the situation in 2006, this decision was based on Serbia's failure to arrest the remaining fugitives, notably Mladić. Refusing to make Serbia's broken promise an absolute stalemate in this stage of the negotiations, the other member states did not follow the Dutch initiative. Instead, the EU designed a temporary agreement, hoping to mobilize domestic progressive forces. ${ }^{64}$ Rehn, for instance, told the press that the Serbian citizens were about to choose 'between a nationalist past and a European future'. ${ }^{65}$ Solana stated that the EU had to show its 'commitment to get Serbia as close as possible to the EU'. ${ }^{66}$ 'We have not forgotten all the conditions', Dimitrij Rupel declared, 'we thought it was important to give Serbia signals at this point of time' ${ }^{67}$ Serbia's pro-reform party, as was hoped, won the subsequent elections, ${ }^{68}$ leading to what Adam Fagan dubs a 'shift towards cooperation with the demands of the EU' ${ }^{69}$

Several authors have tried to explain this surprisingly lenient gesture. ${ }^{70}$ It stands in striking contrast to the popular academic view that enlargement fatigue led to an increasingly severe accession policy. ${ }^{71}$ If the member states indeed felt that further enlargement was undesirable or simply too bothersome, the Dutch reluctance would have offered a perfect pretext to again halt negotiations with Serbia. Security considerations can perhaps explain this seemingly unlikely choice. With Russia's intervention in Georgia and the Arab spring, from an EU perspective the security situation in the Caucasus and the Middle East had worsened. This pushed the EC in 2008 and 2011 to emphasize the need for 'political

64 Braniff, Integrating the Balkans, 127-128; Florence Hartmann, The ICTY and EU Conditionality, in: Judy Batt / Jelena Obradovic-Wochnik, eds, War Crimes, Conditionality and EU Integration in the Western Balkans, Chaillot Papers, no. 116 (2009), 67-82, 67, http://www.iss. europa.eu/uploads/media/cp116.pdf; Christopher Lamont, International Criminal Justice and the Politics of Compliance, Burlington et al. 2010, 85; Noutcheva, European Foreign Policy, 930-936; Peskin, International Justice, 89; Subotić, Hijacked Justice.

65 Olli Rehn, EU Commissioner for Enlargement, What's the Future for EU Enlargement? AmCham EU Plenary Luncheon Keynote Speech, Speech/08/31, 22 January 2008, Brussels 2008, European Commission Press Release Database, http://europa.eu/rapid/press-release_ SPEECH-08-31 en.htm.

66 EU Offers Deal to Serbia, BalkanInsight, 28 January 2008, http://www.balkaninsight.com/ en/article/eu-offers-deal-to-serbia.

67 EU Offers Deal to Serbia, BalkanInsight, 28 January 2008.

68 Adam Fagan, Europe's Balkan Dilemma. Paths to Civil Society or State-Building?, London et al. 2010, 116; Subotić, Hijacked Justice, 80.

69 Fagan, Europe's Balkan Dilemma, 116.

70 Braniff, Integrating the Balkans, 128-129; Hartmann, The ICTY and EU Conditionality, 67; Lamont, International Criminal Justice and the Politics of Compliance, 85; Noutcheva, European Foreign Policy, 930-936; Peskin, International Justice, 89; Subotić, Hijacked Justice.

71 Mathias Dobbels, Serbia and the ICTY. How Effective Is EU Conditionality?, EU Diplomacy Papers 6 (2009), 1-33, 28, https://www.coleurope.eu/research-paper/serbia-and-ictyhow-effective-eu-conditionality. 
stability' in the candidate member states. ${ }^{72}$ Moreover, EC enlargement strategies reveal that the EU increasingly held a credible membership perspective, and thus commitment to its own promises, as being essential in enforcing reforms. ${ }^{73}$

A third reason may again be found in the EU's own experiences with transitional justice. The EU expected Serbia eventually to be willing to do justice and reconcile with its neighbours, as archenemies France and Germany had supposedly done. Enforcing ICTY-cooperation was, after all, part of the EU's state-building strategy. By allowing for negotiation and delay in arresting indictees, the EU could try to influence domestic politics. This illustrates how retributive justice, as demanded by the EU, eventually had to serve democratization and the rule of law in the Western Balkans.

The previous sections linked the EU's expectations of retributive justice, as part of its state-building strategy, to the construction of ICTY-conditionality. Here, the question of effectiveness inevitably arises. Because the focus of this paper lies with the conditionality itself, I will rely here on the most recent conclusions of thorough scholarly work rather than on primary material and reconstruction. As shown by Europeanization scholars looking at the issue through a mainly rationalist lens, contributing to our understanding of the EU's carrot-and-stick approach, conditionality was certainly effective in enforcing ICTY-cooperation and influencing political constellations, especially in comparison with other international bodies. ${ }^{74}$

Research using a socialization approach has nuanced these conclusions. In the case of Croatia, Tina Freyburg and Solveig Richter demonstrated that conditionality's demands often proved incompatible with 'national identity'. Even if cooperation was not politically costly, such a clash resulted in non-compliance. ${ }^{75}$

72 Commission of the European Communities, Enlargement Strategy 2008-2009, 2; European Commission, Enlargement Strategy 2011-2012, 3.

${ }^{73}$ While all enlargement strategies from the year 2005 onwards mention the importance of the membership 'perspective' in motivating the countries to endure the difficult reforms, the 2007-2008 enlargement strategy is the first to fully mimic Schimmelfennig and Sedelmeier's work by stating that 'effectiveness of conditionality in driving reforms depends on maintaining a credible prospect of eventual integration in the Union'. While the 2008-2009 and 2009-2010 strategies are again more implicit on the issue, from 2010 onwards the importance of 'credibility' of the membership perspective is once more emphasized. Hartmann, The ICTY and EU Conditionality, 74; Commission of the European Communities, Enlargement Strategy 2007-2008, 9; European Commission, Enlargement Strategy 2010-2011, 3, 4, 20; European Commission, Enlargement Strategy 2011-2012, 23, 25; European Commission, Enlargement Strategy 2012-2013 COM(2012) 600 final, 3, 23.

74 Dobbels, Serbia and the ICTY, 5-6; Hartmann, The ICTY and EU Conditionality, 67-82, $67,79,81$; Diane Orentlicher, Shrinking the Space for Denial. The Impact of the ICTY in Serbia, Open Society Justice Initiative (2008), 32, http://www.opensocietyfoundations.org/sites/ default/files/serbia_20080501.pdf; Peskin, International Justice in Rwanda and the Balkans, 90.

75 Tina Freyburg / Solveig Richter, National Identity Matters. The Limited Impact of EU Political Conditionality in the Western Balkans, Journal of European Public Policy 17, no. 2 (2010), 263-281, DOI: 10.1080/13501760903561450. 
It is, however, important to look beyond a simple dichotomy of compliance and non-compliance. Instead of looking at effectiveness, these constructivist scholars indeed aimed to study impact. The EU's politically sensitive approach, as described previously, raised possibilities of 'fake compliance' or 'imposed compliance', to use some apt terms from Gergana Noutcheva. ${ }^{76}$ This constructivist input has helped us realize that Europeanization does not only consist of transfer of policies and standards. It includes the complex transfer of norms, values and practices that are more difficult to measure but at least as important in the process of becoming an EU state. For the case of Serbia, several authors have in that light articulated how even formal compliance with ICTY-cooperation did not result in genuine recognition of the court's legitimacy. ${ }^{77}$ Jelena Subotić and Marlene Spoerri, for example, found that the majority of Serbian political actors have never acknowledged justice as a moral necessity. Just as the nationalist discourse in the wake of the refugee crisis and the Turkish coup d'état seemed to intensify rather than retreat after the EU's repeated attempts to enforce norms of solidarity, democracy and human rights, the EU's constant articulation of the norms of justice, peace and reconciliation in the case of ICTY-cooperation has arguably armoured nationalist elites. Depicting ICTY-cooperation merely as a pragmatic choice with direct economic and political benefits, they could mobilize support around their dismissal of the norms the EU membership prospect was expected to enhance. ${ }^{78}$

\section{Claims and Discourse.}

\section{A Retributive Court as Generator of Restorative Justice}

Research thus found a discrepancy between Serbian politicians' compliance with ICTY-conditionality and their internalization of the norms supposedly represented by the ICTY. The disappointing impact of ICTY-conditionality can be explained in terms of a 'mismatch' between the expectations and values embodied by the court, on the one hand, and the concrete conditionality designed to enforce cooperation, on the other hand. The next step in this article, and as I would argue for Europeanization literature in general, is therefore to look again at the claims and expectations of the EU as instigator of the Europeanization process. Admittedly, it seems highly ironic to advocate for this shift back to the EU-level now that scholars have only just recognized the importance of studying the complex and contradictory dynamics of domestic receptivity. As this section will illustrate, however, it is exactly the EU's conviction that Serbia's

76 Noutcheva, European Foreign Policy.

77 Dragović-Soso/Gordy, Coming to Terms with the Past, 197; Noutcheva, European Foreign Policy, 12; Spoerri, Justice Imposed, 1841; Subotić, Hijacked Justice.

78 Spoerri, Justice Imposed; Subotić, Hijacked Justice, 46. 
transitional justice process was to be modelled on EU experience that is key to understanding how ICTY-cooperation within the Serbian context acquired political meanings so different from the norms envisioned by the EU.

The causal relation between international criminal justice and state-building, from an EU perspective, lies in the ICTY's contribution to reconciliation and peace. This three-layered narrative of justice as a step towards reconciliation, which in turn leads to state-building, followed the notion of the Nuremberg court as facilitator of Western European integration. Nuremberg had allegedly paved the way for Western European powers to reconcile peacefully. On the basis of this reconciliation, the former enemies could become one Europe, united by democratization and rule of law. ${ }^{79}$ This EU understanding actually happened to fit in well with the broader discourse of transitional justice, used by practitioners and politicians, as well as scholars. They increasingly embraced international criminal justice as the basis for reconciliation and peace. UN Security Council documents establishing the ICTY confirmed this idea. They stressed the court's contribution to 'lasting peace', 'restoration and maintenance of peace' and '(national) reconciliation' ${ }^{80}$ The ICTY accordingly states on its website that it strives to 'fulfil its mandate of contributing to peace and security in the region' ${ }^{81}$ Even today, scholars defend this idea of the ICTY being the essential constituent of transitional justice and thus of reconciliation and peace. ${ }^{82}$ After an initial trend

79 Delpla, How Has the ICTY Changed Our Perceptions of War?, 553.

80 United Nations General Assembly and Security Council, Report of the International Tribunal for the Prosecutions of Persons Responsible for Serious Violations of International Humanitarian Law Committed in the Territory of the Former Yugoslavia Since 1991 to the United Nations A/49/342, S/1994/1007 13-14, New York 1994, 12; http://www. icty.org/x/file/About/Reports\%20and\%20Publications/AnnualReports/annual_report_1994_ en.pdf; United Nations Security Council, Resolution 808 (1993) S/RES/808, New York 1993, 2, http://www.un.org/en/ga/search/view_doc.asp?symbol=S/RES/808\%281993\%29; United Nations Security Council, Resolution 827 (1994) S/RES/827, New York 1994, 2, http://www. un.org/en/ga/search/view_doc.asp?symbol=S/RES/827\%281993\%29; United Nations Security Council, Resolution 1166 (1998) S/RES/1166, New York 1998, 2, http://www.un.org/en/ga/ search/view_doc.asp?symbol=S/RES/1166\%281998\%29; United Nations Security Council, Resolution 1329 (2000) S/RES/1329, New York 2000, 2, http://www.un.org/en/ga/search/ view_doc.asp?symbol=S/RES/1329\%282000\%29; United Nations Security Council, Resolution 1503 (2003) S/RES/1503, New York 2003, 1, http://www.un.org/en/ga/search/view_doc. asp?symbol=S/RES/1503\%282003\%29; United Nations Security Council, Resolution 1534 (2004) S/RES/1534, New York 2004, 1, http://www.un.org/en/ga/search/view_doc.asp?symbol=S/ RES/1534\%282004\%29.

${ }^{81}$ United Nations International Criminal Tribunal for the former Yugoslavia, Outreach Programme, http://www.icty.org/en/outreach/outreach-programme.

${ }_{82}$ Madoka Futamura / James Gow, The Strategic Purpose of the ICTY and International Peace and Security, in: James Gow / Rachel Kerr / Zoran Pajić, eds, Prosecuting War Crimes. Lessons and Legacies of the International Criminal Tribunal for the Former Yugoslavia, New York et al. 2014, 15-28, 19; Madiha Inara Khan, Historical Record and the Legacy of the Tri- 
to focus on the incompatibility of justice and peace, the academic field now considers them to be mutually enforcing.

However, since the nineties, the academic and practitioners' understanding of transitional justice has quickly evolved. It did not move back to the peace-versus-justice debate, but instead expanded the concept of this justice required to pave the way for peace. Many now emphasize the importance of restorative justice as, at the very least, a complementary mechanism to courts. Recent studies therefore refute the EU's expectation that a single international criminal court, located within the realm of retributive justice, could further restorative goals. ${ }^{83}$ Fact-finding, truth commissions, local initiatives and the involvement of civil society are necessary components of a complete approach to justice that enables long-lasting reconciliation and peace. ${ }^{84}$ Shifting attitudes within the ICTY reflect this change. ${ }^{85}$ The ICTY's personnel generally believe that their main priority lies with prosecution and investigation. They express modesty towards the court's claimed potential for reconciliation. Many believe this can only be an additional and intended consequence of their core task to bring retributive justice. ${ }^{86}$ The ICTY adopted an outreach programme meant to enhance the court's positive impact on peace and reconciliation, but the UN did not consider this a 'core activity'. As a result, the outreach programme relied almost exclusively on donations by the EC. ${ }^{87}$

The EU, meanwhile, severed rather than loosened the discursive link between the ICTY and reconciliation and peace. While an EP resolution from 2007 had already described ICTY-cooperation as 'a key step towards achieving lasting reconciliation in the region' ${ }^{88}$ since 2009 the EU has consistently emphasized this connection, especially in EC enlargement strategies and EP recommendations and resolutions. The EC dubbed cooperation an 'essential' condition and 'key'

bunal for the Former Yugoslavia, in: James Gow / Rachel Kerr / Zoran Pajić, eds, Prosecuting War Crimes, 88-102, 91, 93.

83 Janine Natalya Clark, Judging the ICTY. Has It Achieved Its Objectives?, Southeast European and Black Sea Studies 9 (2009), 123-142, DOI: 10.1080/14683850902723454; Delpla, How Has the ICTY Changed Our Perceptions of War?, 545; Spoerri, Justice Imposed, 1830, 1847; Vukušić, Successes and Failures of Transitional Justice in BiH, 153, 159-161.

${ }^{84}$ Dragović-Soso / Gordy, Coming to Terms with the Past, 208; Smeulers / Grünfeld, International Crimes and Other Gross Human Rights Violations, 465.

85 Vukušić, Successes and Failures of Transitional Justice in BiH, 161-162.

86 Interview with A.A. (ICTY Belgrade office staff member), 7 July 2012; Clark, Judging the ICTY, 133; Futamura / Gow, The Strategic Purpose of the ICTY, 20.

87 Janine Natalya Clark, International War Crimes Tribunals and the Challenge of Outreach, International Criminal Law Review 9, no. 1 (2009), 99-116, 105, DOI: 10.1163/157181209X398835.

${ }^{88}$ European Parliament, European Parliament Recommendation to the Council of 25 October 2007 on Relations Between the European Union and Serbia P6_TA(2007)0482, Strasbourg 2007, 3, http://www.europarl.europa.eu/sides/getDoc.do?type=TA\&reference=P6-TA-20070482\&language $=\mathrm{EN}$. 
in achieving 'lasting reconciliation in the region' ${ }^{89}$ As early as 2009 the EP had concluded that the ICTY had 'already made a significant contribution' to reconciliation and peace in the region. ${ }^{90}$ In 2009 and 2012 the EP urged the Western Balkan societies to see extraditions of war criminals as not only a membership condition, but 'above all a step towards bringing justice to the victims [...] and reconciliation in the region'. ${ }^{91}$ When in 2011 the last remaining fugitives of the ICTY were arrested, the EC praised the extraditions of Mladić and Hadžić as 'marking an important step towards reconciliation' ${ }^{92}$ The conditionality's focus on arrests was thus directly connected to the EU's broader expectations of the court's restorative potential. This link permeated the Serbian side of the diplomatic relations, with official documents declaring that 'an awareness has been developed that fulfilment of the ICTY's mandate will contribute to the reconciliation among peoples in the region'. ${ }^{93}$ With this discourse, the EU actively carried out a message that was debated within the wider academic community and that even went beyond claims of the court itself.

\section{A New Take on the Impact of Conditionality. Balancing Retributive and Restorative Justice}

This article has illustrated that the justification for ICTY-conditionality rested upon two pillars. First, the EU enforced ICTY-cooperation as an international obligation to which all Western Balkan states had to adhere. Second, based upon its own experiences with the Nuremberg trials, the EU became the most vocal supporter of the ICTY's contribution to reconciliation as a first step towards state-building. Combining the two, the EU established the ICTY as an international retributive court in a discourse of restorative justice. This, I argue here, raises a new perspective that helps in seeing the complexities and nuances of ICTY-conditionality's impact.

89 European Commission, Enlargement Strategy 2011-2012, 8; European Commission, Enlargement Strategy and Main Challenges 2012-2013, 7.

90 European Parliament, European Parliament Recommendation to the Council of 12 March 2009 on the Mandate of the International Criminal Tribunal for the Former Yugoslavia P7_TA(2009)0136, Strasbourg 2009, 2, http://www.europarl.europa.eu/sides/getDoc.

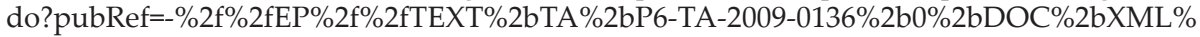
$2 \mathrm{bV} 0 \% 2 \mathrm{f} \% 2 \mathrm{fEN} \&$ language $=\mathrm{EN}$.

${ }^{91}$ European Parliament, European Parliament Resolution of 26 November 2009 on the Commission's 2009 Enlargement Strategy Paper Concerning the Western Balkan countries, Iceland and Turkey P7_TA(2009)0097, Strasbourg 2009, 3, http://www.europarl.europa.eu/ sides/getDoc.do?type=TA\&reference=P7-TA-2009-0097\&language=EN; European Parliament,

Enlargement Report for Serbia 2012, 3.

92 European Commission, Enlargement Strategy 2011-2012, 3.

93 Republic of Serbia, Amended National Programme, 40. 
There are two ways to interpret the impact of this duality. Spoerri concluded in 2011 that the EU's carrot-and-stick policy revolving around deadlines and rewards, as explored already in this paper, drew attention away from the ICTY's and other initiatives' restorative potential. ${ }^{94}$ Here, the focus is on the EU's failure to enhance restorative justice. The second way to interpret the impact does not necessarily refute this analysis, but it derives from a different logic. Instead of arguing that the EU should have done more to further the ICTY's restorative potential, I posit that it was exactly the ICTY's restorative discourse that turned out to be the most problematic part of the EU's approach. Close examination of a quote by Heather Grabbe illustrates the far-reaching implications of the EU's consistent emphasis on the ICTY's contribution to reconciliation. Commenting on the arrest of Mladić in 2011, Rehn's senior advisor described the breakthrough 'as a symbol that Serbia is ready to put the past behind it'.$^{95}$ This enabled domestic actors to see ICTY-cooperation on par with successfully dealing with the past. Politicians interested in distorting transitional justice could thus deny the importance of domestic initiatives aimed at restorative justice.

Both analyses of the ICTY-conditionality's impact are challenged by reference to a recent, promising initiative from the region that actually received EU support from its start. ${ }^{96}$ About a decade ago, several civil society organizations in the Western Balkan region started the RECOM 'process'. This 'non-political gathering' formed a coalition and aims to establish a Regional Commission Tasked with Establishing the Facts about All Victims of War Crimes and Other Serious Human Rights Violations Committed on the Territory of the Former Yugoslavia in the Period from 1991-2001. The first preamble of its (proposed) statute declares that the 'Parties to the Agreement on the Regional Commission' [are]:

'mindful that the trials held before the ICTY and before national courts, although contributing significantly to punishing war crimes perpetrators, do not fully satisfy victims' needs for justice and are insufficient for the creation of the conditions necessary to achieve a lasting peace in the region. ${ }^{97}$

94 Spoerri, Justice Imposed, 1838-1840.

95 Stephen Castle, Mladic Arrest Opens Door to Serbia's Long-Sought European Union Membership, New York Times, 26 May 2011, http://www.nytimes.com/2011/05/27/world/ europe/27union.html?_r=0.

96 Iavor Rangelov's statement that the EU 'ignored' domestic transitional justice mechanisms thus also seems to be outdated cf. Iavor Rangelov, EU Conditionality and Transitional Justice in the Former Yugoslavia, Croatian Yearbook of European Law and Policy 2 (2006), 365-375, 368, http://www.cyelp.com/index.php/cyelp/article/view/24.

97 Coalition for RECOM, The Statute (Proposal) of the Regional Commission Tasked with Establishing the Facts about All Victims of War Crimes and Other Serious Human Rights Violations Committed on the Territory of the Former Yugoslavia, 26 March 2011, 3, http:// www.recom.link/wp-content/uploads/2012/01/Proposed-Statute.pdf. 
Resembling the current emphasis on restorative justice, RECOM's approach exceeds the definition of international criminal justice as used by the ICTY. In terms of goals, it presents itself as complementary to the ICTY. ${ }^{98}$ It acknowledges that the ICTY has been of major importance to achieving legal justice and holds that this paved the way for such a truth-finding initiative. The founders conclude that true and fully satisfactory justice requires a focus on the victims' needs for truth and restorative justice. ${ }^{99}$ The EC and EP have recognized and supported RECOM in their reports and resolutions as well as in terms of financial help. ${ }^{100}$ They have praised the initiative's potential for reconciliation in the region, especially after the arrests of the last ICTY-fugitives. ${ }^{101}$ RECOM's founders differ in their evaluation of EU support, but generally agree that the endorsement of the EC especially will have a positive impact on RECOM's work. ${ }^{102}$

The EU's, albeit relatively modest, support for RECOM puts my puzzle in a new perspective. At the very least, the findings add nuance to the dominant academic view that the EU was mostly, if not exclusively, committed to straightforward compliance with the ICTY for the mere sake of arresting fugitives. The analysis moreover indicates that the EU did acknowledge restorative justice as a legitimate part of transitional justice. Yet does that also attest to true recognition of the urgent need for restorative transitional justice mechanisms in the Western Balkans? The discourse of restorative justice was far from new because the EU had used it to justify its ICTY-conditionality. RECOM was therefore quite straightforwardly incorporated in this same discourse. This undermined acknowledgement of RECOM's novelty and potential. Whereas the EU seemed to understand that RECOM wishes to 'follow-up' on the ICTY's work, the EU did little to stress the essentially different approaches of both institutions.

98 Simić, The European Union and the Western Balkans, 198.

99 Interview with Marijana Toma (Deputy Executive Director of the Humanitarian Law Center, Belgrade), 13 July 2012.

$10080 \%$ of RECOM's budget comes from The European Instrument for Democracy and Human Rights and the Dutch embassy cf. Simić, The European Union and the Western Balkans, 200.

101 European Commission, Enlargement Strategy 2010-2011, 9; European Commission, Enlargement Strategy and Main Challenges 2011-2012, 8; European Commission, Analytical Report, 4; European Commission, Serbia 2012 Progress Report, 20; European Commission, Enlargement Strategy 2012-2013, 7; European Commission, Communication from the Commission to the European Parliament and the Council, Enlargement Strategy and Main Challenges 2013-2014 COM(2013) 700 final, Brussels 2013, 14, http://ec.europa.eu/enlargement/pdf/ key_documents/2013/package/strategy_paper_2013_en.pdf; European Commission, Serbia 2013 Progress Report, 1; European Parliament, Stabilisation and Association Agreement, 4; European Parliament, Enlargement Report for Serbia 2012, 10; European Parliament, European Parliament Resolution of 18 April 2013 on the 2012 Progress Report on Serbia P7_TA(2013)0186, Strasbourg 2013, 12, http://www.europarl.europa.eu/sides/getDoc.do?pubRef=-//EP//TEX$\mathrm{T}+\mathrm{TA}+\mathrm{P} 7-\mathrm{TA}-2013-0186+0+\mathrm{DOC}+\mathrm{XML}+\mathrm{V} 0 / / \mathrm{EN} \&$ language $=\mathrm{HR}$.

102 Simić, The European Union and the Western Balkans, 200-201. 
In that sense, president of the Humanitarian Law Centre Nataša Kandić's warning is still valid: political actors uninterested in resolving questions of truth and accountability can claim that with the end of Serbia's ICTY-cooperation 'the general process of dealing with the past has been concluded too'. ${ }^{103}$ Now that all fugitives have been arrested and the ICTY is to close down in the foreseeable future, this is all the more relevant. By incorporating the ICTY in its state-building strategy, the EU has associated itself with transitional justice in practice as well as in discourse. Serbian politicians could thus present every step towards the EU, most notably Serbia's acquisition of candidate member status in 2012, as a step towards successfully dealing with the past. The enlargement strategy needs to overcome the comparison with the Nuremberg trials - a parallel based on an identity narrative rather than sound history - to underscore both the actual value and limitations of the ICTY. In short, the EU needs to acknowledge that the process of restorative justice still has to start.

\section{Conclusion}

This paper combines historical reconstruction and interpretive policy analysis to help in understanding how the EU's expectations of post-conflict transition shaped ICTY-conditionality. Instead of looking directly for the impact of the EU's disregard for restorative justice, this paper asks why the EU chose to engage with retributive transitional justice. This leads to new insights with which to evaluate the impact of ICTY-conditionality.

The EU projected its own post-Second World War foundational narrative on the war-torn Western Balkans. In parallel with the perceived successes of Nuremberg, the ICTY's retributive justice was expected to lead to reconciliation, as a basis for building future European member states. Conditionality as the 'cornerstone' 104 of enlargement proved effective in enforcing this cooperation. However, this tool also had a problematic side. Formulated broadly, evaluated narrowly and implemented flexibly, it made the notion of justice vulnerable to political opportunism and distortion. This became even more problematic in the wider restorative-justice discourse of peace and reconciliation in which the EU embedded the ICTY-condition. In parallel with the Nuremberg trials, which were understood to have paved the way for the peaceful and democratic Western European future, the EU consistently emphasized that ICTY-cooperation would lead to reconciliation as the foundation for democratization and rule of law. This causal link has received its fair share of criticism from practitioners,

${ }^{103}$ Nastaša Kandić, as cited in: Dinko Gruhonjić, The Ghost of Milošević Still Haunts Serbia, RECOM Initiative !Voice 4 (2012), 18-19, 18, http://www.centar-za-mir.hr/uploads/ RECOM_Initiative_Voice_4_2012_ENG_1.pdf.

104 Schimmelfennig, EU Political Accession Conditionality, 918. 
including those within the ICTY, and academics alike. Recent initiatives like RECOM try to make up for the exclusive focus on retributive justice. There is a risk, nevertheless, that the EU's discourse of the ICTY's contribution to reconciliation limits RECOM's restorative potential.

Thus, parallel to the need for Europeanization scholars to rethink the meaning and impact of the EU's expectations, the EU itself needs to acknowledge that the question 'what is best for Serbia?' is too simplistically answered: 'that which is best for the EU'. It is not difficult to understand how Eurosceptic and nationalist elites could use this to their advantage, creating a schism between the EU's attempted state-building and these elites' envisioned nation-building. This line of thought becomes even more pressing if we consider the ongoing fragmentation in the EU over the bailout of Greece and the so-called 'refugee crisis'. If the EU could not find the glue to hold it together, nor define its identity, but did project its own experiences on a topic so contested and sensitive to nationalism as dealing with the past, then what exactly did it offer to the Western Balkans?

This article, however, also proposes a more optimistic prospect for Europeanization scholars and the EU. This is based on another, by now widely accepted, conclusion of Europeanization: norms transfer is, or should always be, a twoway process. ${ }^{105}$ While RECOM as a regional project showed the deficiencies in the EU's transitional justice approach, it also benefited from the strong, albeit insufficient, incorporation of transitional justice in the EU's state-building strategy. If the EU gradually extends its priorities to inclusive transitional justice, inspired by RECOM's bottom-up input, ${ }^{106}$ this may grant the political legitimacy normally reserved for the 'hard' ambitions of democratization and rule of law to the often considered 'soft' restorative-justice goals. Future follow-up research may conclude that ICTY-conditionality has made regional leaders acknowledge transitional justice as a standard component of political transition. Such recognition can be the 'missing link' between justice, reconciliation and state-building in the Western Balkans.

\section{CORRESPONDING AUTHOR}

Niké Wentholt University of Groningen, Faculty of Arts, P.O. Box 716, 9700 AS Groningen, The Netherlands. E-mail: nikewentholt@gmail.com

105 Tanja A Börzel, Building Member States. How the EU Promotes Political Change in its New Members, Accession Candidates, and Eastern Neighbours, Geopolitics, History, and International Relations 8, no. 1 (2016), 76-102, 101, https://www.ceeol.com/search/article-detail?id= 342931.

106 In 2012, the EP adopted a resolution that emphasized the importance of civil society in enhancing reconciliation and urged the EC to support such initiatives aimed at increasing tolerance and dialogue. European Parliament, Consolidating Stability and Prosperity in the Western Balkans. 